\title{
SOCIAL JUSTICE IN PLATO'S REPUBLIC
}

\author{
Robert Heinaman
}

In two papers on the Republic ${ }^{1}$ Gregory Vlastos argued that, insofar as it concerns the distribution of goods or 'the allocation of substantive rights, ${ }^{2}$ social justice was determined for Plato by 'the Principle of Functional Reciprocity':

(FR) All members of the polis have equal right to those and only those benefits which are required for the optimal performance of their function in the polis.

As everyone knows, Plato's ideal state divides into three classes - producers, auxiliaries and guardians - which perform different roles to promote the city's wellbeing. Producers furnish the material necessities of life, auxiliaries form an army to protect the city from external and internal enemies, and guardians rule. According to FR, one's rights are determined by the class to which one is assigned and by one's specific task within that class: provided that one actually performs one's function or work, ${ }^{4}$ one receives whatever

1 'The Theory of Social Justice in the Polis in Plato's Republic', Studies in Greek Philosophy II (Princeton, 1995), pp. 69-103; originally printed in Helen North, ed., Interpretations of Plato (Leiden, 1977) (Mnemosyne, Suppl. vol. 50), pp. 1-40; 'The Rights of Persons in Plato's Conception of the Foundation of Justice', Studies in Greek Philosophy II, pp. 104-25; originally published in H. Tristram Englehardt, Jr., and Daniel Callahan, eds., Morals, Science and Society (Hastings-on-Hudson, N.Y., 1978), pp. 172-201. All page references are to the articles as published in Studies in Greek Philosophy II.

2 'Social Justice', p. 86.

3 'Rights of Persons', p. 110.

4 'Rights of Persons', pp. 112, 123. In FR 'one's work' refers solely to one's specific task or role, such as shoemaking or cobbling. But Vlastos allows that the phrase can also refer to the entire range of public and private obligations governing one's conduct, and many of these obligations are not tied to one specific job such as shoemaking ('Social Justice', p. 79): 'this 'single service in the polis' ['doing one's own'], though vocationally based, is not meant to be restricted to on-the-job activity but to extend over the whole of one's conduct in the polis, private no less than public.'

Vlastos is correct to recognize this broad use of 'doing one's own', and hence of 'justice.' (See, for example, 441d-e and 443a). But he does not appear to realize that this recognition conflicts with his previously argued claim that in the Republic $\delta \iota \kappa \alpha \iota \sigma \beta \nu \eta$ is restricted to the narrow use of the term ('Social Justice', pp. 73-78). If justice is 'doing one's work' and 'one's work' refers to 'the whole of one's conduct 
goods one needs in order to carry out one's job. One receives no other goods and, in particular, one is denied anything that might damage one's ability to perform one's job as well as possible.

At the same time, Vlastos argued against the view that social justice in the Republic is based on proportional equality, the account of justice which in ancient times was set out most fully by Aristotle. According to proportional equality, ${ }^{5}$ justice exists when goods are distributed to people in proportion to their merit or desert (á) $\left.\xi^{\prime} a\right)$. In the simplest case involving two people - A and $\mathrm{B}$ - justice exists when the ratio of the value of the good assigned to A to the value of the good assigned to $\mathrm{B}$ equals the ratio of the merit of $\mathrm{A}$ to the merit of B -

The merit of A
The value of the goods assigned to A
The merit of B
The value of the good assigned to $B$.

Clearly, this idea of proportional equality is very general and loose, and as stated so far it is compatible with all sorts of views about distributive justice, depending on how we identify the goods to be distributed, their value, and the merit of the people who receive them. Thus, when Aristotle discusses the just distribution of political power, he refers to disagreements about what the relevant merit is which validates its possession. ${ }^{6}$ Democrats maintain that what determines a person's merit is being a free citizen, and therefore, since all free citizens equally share this merit, all deserve an equal amount of political power. Since all free citizens cannot occupy political office at the same time, office holding is settled by lot. Oligarchs, on the other hand, maintain that political power should be distributed on the basis of the possession of a certain degree of wealth, while aristocrats maintain that it is virtue which warrants the possession of political power. ${ }^{7}$

According to Vlastos, when considering the Republic's account of political justice we should forget all about proportional equality. ${ }^{8} \mathrm{I}$ believe that this is a mistake and that proportional equality plays an important role in the $R e$ -

in the polis', then this must be justice in the broad use which is identical with virtue as a whole.

${ }^{5}$ For a good exposition of Aristotle's position, see D. Keyt, 'Aristotle's Theory of Distributive Justice', in D. Keyt and F. Miller, Jr. (eds.), A Companion to Aristotle's Politics (Oxford, 1991), pp. 240-47.

${ }^{6} N E$ 1131a24-29; cf. Pol. 1280a18-19, 1282b14-23. Aristotle also claims that people agree about the value of the goods distributed (Pol. 1280a18-19).

${ }^{7}$ Cf. Rep. 549a, 550c-d 551a-b, 557a, 558c, 562b-c.

8 'Social Justice', p. 89. 
public's account of social justice. ${ }^{9}$ The first part of my paper will try to show that Vlastos' arguments against so interpreting the Republic are not convincing. I do not claim that Vlastos is wrong to think that a principle along the lines of FR plays an important role in the Republic. Rather, I believe that Vlastos failed to see how easily the idea behind his principle could be absorbed by the notion of proportional equality. Furthermore, while this idea behind FR plays a significant part in Plato's account of justice, it is insufficient as a full account of social justice in the Republic because, as I will argue in the second part of the paper, there are several important decisions which Plato makes about the distribution of goods which FR cannot explain. On the other hand, these decisions can be explained on the basis of proportional equality.

\section{I}

Vlastos' position is based on the contention that Plato makes certain choices about the distribution of goods in the city which conflict with the distribution required by proportional equality. He makes four points which I will consider in turn.

(1) Vlastos says that, apart from the distribution of honour, 'Platonic justice would flout 'proportional' equality . . . - by giving less of some of the major means of happiness to those who give the polis more'. ${ }^{10} \mathrm{By}$ 'the major means of happiness' Vlastos means a normal sexual and family life, and private property. These are denied the guardians - 'those who give the polis more' - on the grounds that such goods would undermine the guardians' ability to rule the city properly.

Here Vlastos takes the fact that the guardians do not get certain goods to show that they are not distributed on the basis of proportional equality. Therefore, he must be assuming that the guardians would merit or deserve these goods according to proportional equality. And so he is assuming that

${ }^{9}$ Vlastos ('Social Justice', p. 87, n. 84) refers to the following authors as holding that proportional equality is upheld in the Republic: E. Barker, Greek Political Theory (New York, 1951), p. 139, n. 2; K. Bringmann, Studien zu den politischen Ideen des Isokrates (Hypomnemata, no. 14, 1965), p. 86; R. Maurer, Platons 'Staat' und die Demokratie (Berlin, 1970), p. 75f. I have not been able to obtain Bringmann's book. See also E. Barker, The Political Thought of Plato and Aristotle (New York, 1959), p. 20, n. 1; J. Derbalov, 'Ursprungsmotive und Prinzipien der Platonischen Staatsdenkens', Kantstudien, 55 (1964), pp. 274-76, 290. Cf. also M.B. Foster, 'On Plato's Conception of Justice in the Republic', Philosophical Quarterly, 1 (1951/52), p. 209.

10 'Social Justice', pp. 88-89. There is some unclarity about what Vlastos believes determines merit according to proportional equality. In the passage under discussion he assumes that proportional equality would say that one merits or deserves goods in proportion to one's degree of contribution to the good of the city. But he also assumes that it would say that the basis for deciding one's merit is one's degree of virtue (p. 89). 
proportional equality is committed to the following: what one deserves is determined by what contribution one makes to the wellbeing of the city, and what one's contribution to the wellbeing of the city entitles one to is all socially distributable goods in proportion to the scale of one's contributions.

One problem here is Vlastos' assumption that Plato regards the items in question as among 'the major means of happiness.' Plato, of all people, does not set a high value on possessions $;{ }^{11}$ nor does the Republic ${ }^{12}$ or the Symposium suggest that he regards a family or sexual relations as among 'the major means of happiness.' In his opinion, the guardians are given the best life possible, and the belief that the items in question are necessary for happiness is dismissed as 'a foolish adolescent opinion about happiness' (Republic 465d466b). Since Plato rejects Vlastos' assumption, even if proportional equality said that 'the major means of happiness' should be distributed in proportion to people's contribution to the wellbeing of the city, it would not imply that the guardians should receive more of the goods in question than anyone else. So the fact that Plato does not allow such items to be distributed to the guardians would not show that distributive justice in the Republic is not determined by proportional equality.

More seriously, Vlastos' argument rests on a misunderstanding of the idea of proportional equality, for that idea can easily assimilate the point behind FR and explain Plato's decision about the distribution of the goods which Vlastos says are among 'the major means of happiness'.

Proportional equality does not say that people should receive all goods to that degree which matches their degree of virtue. Nor does it say that people should receive all goods to that degree which matches their contribution to the city's wellbeing. Proportional equality can allow that 'what people merit' will be determined by different factors in different cases, depending on what good is being distributed and for what purpose. There is no reason why the question of how the possession of a good would affect one's ability to perform one's function may not be among the considerations which determine what one merits when certain goods are distributed. Thus, in the Laws (744bc), where justice is explained in terms of proportional equality (756e-758a), Plato points out that it is not virtue alone which determines the merit $(\dot{a} \xi i a)$ that grounds the distribution of burdens and benefits according to proportional equality.

Vlastos seems to be making a mistake which Aristotle criticizes when explaining his view of social justice, viz. the mistake that results when people think that if they are equal (or unequal) in one respect, they are equal (or unequal) in all. ${ }^{13}$ Aristotle discusses an example where the question is how to distribute justly a limited number of flutes. He does not think that the flutes should be distributed to those who have the greatest virtue of character or to

\footnotetext{
${ }^{11}$ Cf. Rep. 485d-e, 491c, 493d, 495a, 547b, 559b-c.

${ }_{12}^{12}$ Rep. 395d-e, 402e-403c, 485d-e.

${ }^{13}$ Pol. 1280a21-25; cf. 1282b18-30, 1283a26-27, and Rep. 551b-d.
} 
those who have contributed most to the wellbeing of the polis, or to those who are better born or more beautiful.

\begin{abstract}
Among fluteplayers who are equal in the art we should not give the preference of flutes to the more nobly born, because they will not play any better. We should give the superiority in instruments to him who is superior at the

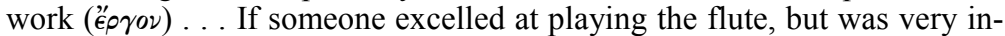
ferior in birth or beauty, then, even if each of these is a greater good than fluteplaying (I mean birth and beauty), and even if their superiority to fluteplaying is proportionately greater than his superiority as a fluteplayer, still he should be given the outstanding flutes. For their superiority must contribute to the work (éprov); but superiority in wealth and birth contribute nothing. ${ }^{14}$
\end{abstract}

For Aristotle, proportional equality maintains that what determines merit in specific cases will depend on what good is being distributed, and on the purpose for the sake of which it is being distributed. ${ }^{15}$ So if flutes are being distributed for the purpose of organizing an orchestra to play music as well as possible, then merit is determined by flute playing skill, by who can do the work that accomplishes the end in view. As far as the distribution of this good for this purpose goes, it does not matter how virtuous or vicious those with flute playing skill may be.

Plato makes a similar point in the Republic (453d-455a) when he is considering how to distribute functions or tasks, and starts to justify his belief that women should be assigned the same jobs as men. Earlier, ${ }^{16}$ Socrates had said that for justice to be realized in the city, people with different natures

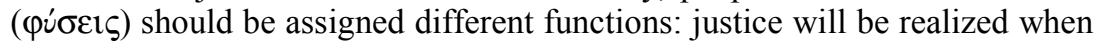
people do their own work according to nature (453b). Since men and women differ in nature, the proposal for women to be given the same jobs as men might appear to contradict the earlier rule on the assignment of tasks. Plato now points out that the contradiction is only apparent. In saying that different natures should be assigned different jobs, he did not mean that if our present

${ }_{15}^{14}$ Pol. 1282b33-1283a3. Richard Robinson's translation.

${ }^{15}$ Cf. Pol. 1280a25-36, and III.9 as a whole, where the determination of political justice rests on determining what a polis is, which depends on determining the end of the polis. According to Aristotle, it is the fact that what determines merit depends on the purpose of the community in question which is 'the main point' (1280a25) missed by those who think that if they are equal in one respect they are equal in all, and by those who think that if they are unequal in one respect they are unequal in all (1280a16-24).

As $N E 1160$ a8-25 shows, the purpose is closely tied to the kind of association

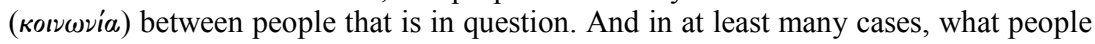
merit depends on what relations exist between the associated parties. For example, in the association of a father with a son, or a husband with a wife, 'the justice . . that exists between persons so related is not the same on both sides but is in every case proportional to merit' (NE 1161a21-22; cf. IX.2).

${ }^{16}$ Rep. $412 \mathrm{~b}-415 \mathrm{~b}$. 
day shoemakers are bald-headed, then hairy men should be banned from shoemaking on the grounds that they differ in nature. Although they do, in a way, differ in nature, it is not a difference that is relevant to the question of who should be a shoemaker.

People are alike and different in various respects, and in assigning jobs we must specify what difference in nature is relevant. This is done, Plato says, by making it clear what it is with reference to which natures are to be distinguished; and this determining factor is the task to be performed. ${ }^{17}$ If we must look to the purpose for the sake of which an item is being distributed, then just as beauty is irrelevant in deciding who should be given flutes, so degree of hairiness is irrelevant in deciding who ought to be a shoemaker or a soldier. The items in question should be distributed to those with the relevant ability for performing the task in question. Since difference in sex does not necessarily affect the capacity to perform the jobs to be done in the city, i.e. does not affect one's 'nature' in the relevant sense, women will often merit the same jobs as men. ${ }^{18}$

The view that the just distribution of goods to people depends on the 'natures' of the recipients is repeated in the Laws (757c), where Plato explicitly defends the view that political justice is based on proportional equality. ${ }^{19} \mathrm{He}$ explains that proportional equality involves granting 'more to the greater person and less to the lesser person, adjusting what you give to take account of

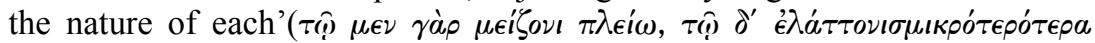

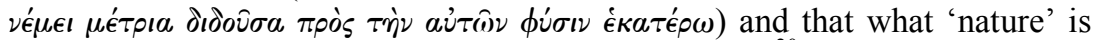
relevant depends on the kind of good being distributed. ${ }^{20}$

The idea of what one deserves or merits is very elastic, and one can adopt the idea of proportional equality while at the same time maintaining that all sorts of factors determine merit or worth in different cases. If prizes in a race are awarded, then merit is determined by swiftness. ${ }^{21}$ Or suppose people have associated in a business with different individuals contributing different amounts to the original investment. ${ }^{22}$ Other things being equal, profits are

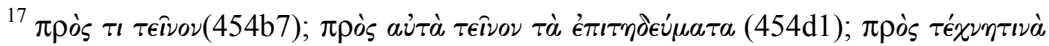

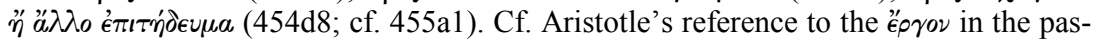
sage quoted above; and Plato's reference to ép $\rho a$ which, he goes on to argue, the nature of a woman allows her to achieve in common with men (453a2). In so far as

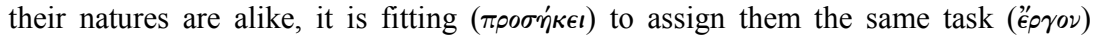
(453b10). - Note that, in these texts, 'є́prov' refers to the task or job one is assigned, and this does not necessarily coincide with the end with regard to which it is decided what natures are appropriately assigned a specific job. But a distinction between work and its goal does not play any explicit role in Plato's argument.

${ }^{18}$ Cf. Laws 715b-c, and R. Maurer, Platons 'Staat' und die Demokratie, pp. 7576.

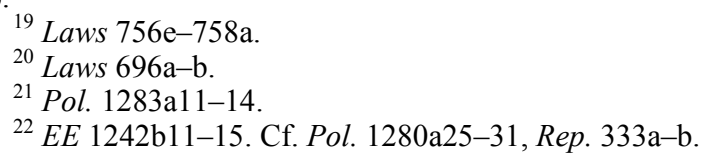


distributed justly when they are distributed proportionately to the original sum invested, so that those who invested more get more in return, and those who invested less get less in return. Here again, the virtue or vice of the people involved is irrelevant to determining what counts as a just distribution of money. What determines one's merit is the relative size of one's original investment.

So it is easy to see how the idea of proportional equality can be made consistent with Plato's decision about the distribution of the items Vlastos referred to in his argument. When the basic structure of the city is being decided, and the goods distributed to the members of the ideal polis are the rights to a normal sexual life and family life, and the right to own private property, then the goal with regard to which we decide what is just will be the overriding aim of the distribution of all goods in the city - the wellbeing of the city as a whole, which requires that the essential tasks in the city be performed as well as possible. With this goal in mind, one will merit what one needs to make one's greatest contribution to the wellbeing of the city in the performance of one's function, and one will not deserve any item which would threaten one's ability to thus contribute to the wellbeing of the city. Since Plato believes that the items mentioned by Vlastos would harm the guardians' ability to rule, they are denied those goods - they do not merit them.

In other words, the idea of proportional equality can absorb Vlastos' idea and say that, for the distribution of many goods, what one deserves at least partly depends on how the possession of that good affects one's ability to do one's job in contributing to the city's wellbeing. ${ }^{23}$

(2) What I have just said also provides part of the answer to Vlastos' first objection to proportional equality in 'Rights of Persons. ${ }^{24}$ Consider, he says, a flutemaker in Plato's ideal city with the skill to become much richer than other members of the producing class while working far less. FR explains why Plato would not allow the flutemaker to get away with this - having more money, property and leisure than others would not enable him to do his job any better, so he will not be allowed to have them. On the other hand, Vlastos claims, proportional equality will not explain Plato's decision: 'why shouldn't the flutemaker claim that the merit of his superior talent is so much greater than [the talent] of mere shoemakers and the like that it entitles him to vastly greater social benefits? ${ }^{25}$ So, according to Vlastos, FR explains why

${ }^{23}$ Vlastos' second argument in 'Rights of Persons' (pp. 117-18) is basically the same as the argument just considered, differing only in that the latter argument assumed that proportional equality positively demands that the guardians be given the goods which Plato denies them, while the argument in 'Rights of Persons' merely claims that nothing in the idea of proportional equality can explain why Plato denies the guardians private property and a family.

24 'Rights of Persons', p. 115.

${ }^{25}$ Ibid. 
Plato rules out inequalities of a sort which proportional equality would tolerate.

The reply is that Plato can allow that in laying down a general policy for how much accumulation of wealth is to be permitted, and on how much inequality of wealth may exist, the effect of these factors on the ability of people to perform their work must be taken into account in deciding what people deserve. ${ }^{26}$ Since, Plato believes, excessive wealth and leisure would render the flutemaker unfit to perform his function, he will not merit these goods and will not receive them. Thus in the Laws, ${ }^{27}$ we find that Plato appeals to proportional equality in ruling that neither poverty nor excessive wealth should be allowed in the city whose constitution is being devised.

Later I will argue that Plato's second argument for his account of social justice shows that FR is unable to handle the Republic's position concerning private property.

(3) In the guardian class, Plato thought that women should be treated in the same way as men. They would have the same rights to education, work, social intercourse, and the same sexual, legal and political rights as men. According to Vlastos, Plato's position is based on FR: 'membership in the guardian class should be as open to women as to men . . on the ground that biological femaleness is irrelevant for good performance in any recognized work role. ${ }^{28}$

On the other hand, we can see, Vlastos says, that proportional equality will not yield these results by considering the Laws (756e-758a), where justice is determined by proportional equality, and women no longer have the same legal, political or vocational rights which Plato granted them in the Republic.

How exactly Plato would have thought that the justice of these inequalities is validated by $\mathrm{PE}$ is unclear. What is clear is that this principle is so vague and loose that it can offer no resistance to them, while if FR were being applied it would have ruled them out as firmly here [in the Laws] as previously in the $R[$ epublic $] .^{29}$

There are four points to be made in response to this argument. First, I have already explained how the Republic's defence of its treatment of women is very close in thought and language both to Aristotle's account of justice in terms of proportional equality, and to the Laws' account of political justice in terms of proportional equality.

Secondly, Vlastos' characterization of the position of women in the Laws is quite misleading. To support it, he refers to Glenn Morrow's book, Plato's Cretan City. But Morrow correctly points out that, in the Laws, 'Women are

\footnotetext{
${ }^{26}$ Rep. $421 \mathrm{c}-422 \mathrm{a}$.

${ }^{27}$ Laws 744a-745b.

28 'Rights of Persons', p. 117.

${ }^{29}$ Ibid.
} 
to share with men, to the greatest extent possible, in all the activities and duties of the state. ${ }^{30}$

Thirdly, even setting aside these points, Vlastos would only have succeeded in indicating that social justice is not exhausted by the idea of proportional equality. But that is clear in any case. As we have seen, the belief in proportional equality does not by itself determine what the goods are whose distribution is to be governed by proportional equality. Nor does it specify what factors are to be taken into consideration in determining the merit or worth of the people who are to receive the goods. Even if Vlastos' view of the position of women in the Laws were correct, Plato could have accepted proportional equality in both the Republic and the Laws while changing his mind between the two dialogues on the question of what women merit - just as, between the two dialogues, he changed his mind on the question of what kind of political power philosophers merit. ${ }^{31}$

Finally, this objection can be thrown back at Vlastos, for FR fails to explain why anyone, male or female, is given power in Plato's ideal city. This will be explained in the second half of the paper. (See (7) in section II).

(4) A final point which Vlastos makes is this:

Nor is it clear how P[roportional] E[quality] could have sustained the sense of affectionate partnership between the powerful elite and the powerless mass which Plato is counting on to provide the morale of the just society . . . Fraternal solidarity is what he has in view, affection generated in a working relationship where the sense of interdependence is heightened to the nth degree as each of the partners feels that his own work gets the benefit of the best that the others have it in them to give. It is the FR principle that provides the basis for the emotional unity of the class-stratified Platonic polis. ${ }^{32}$

This is a strange argument, for it seems clear that on this question FR explains nothing and proportional equality is the relevant consideration. According to FR, 'all members of the polis have equal right to those and only those benefits which are required for the optimal performance of their function in the polis. ${ }^{33}$ So if the Republic's principle of distributive justice

${ }^{30}$ G. Morrow, Plato's Cretan City (Princeton, 1960), p. 331. See Laws 781b, $785 \mathrm{~b}, 805 \mathrm{a}, \mathrm{c}-\mathrm{d}, 806 \mathrm{c}$. This does not mean that the position of women is in all respects equivalent to that of men. See, for example, 937a.

${ }^{31}$ See Laws 713c, 875a-d and 691c-d:

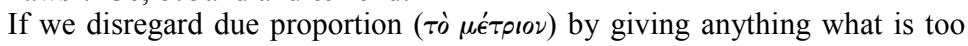
much for it, too much canvas to a boat, too much nutriment to a body, too much authority to a soul, the consequence is always shipwreck ... [I]ts issue is injustice ... No soul of man while young or accountable to no control, will ever be able to bear the burden of supreme power among men without taking the taint of the worst spiritual disease, folly ... Hence it calls for a great legislator to forestall this danger by his insight into due proportion.

32 'Rights of Persons', pp. 118-19.

33 'Rights of Persons', p. 110. 
applies to the amount of love which citizens are entitled to, then FR yields the result that one is only entitled to that amount of affection from other members of the polis which is required to enable one to perform one's job as well as possible. But it is extremely implausible to suggest that a shoemaker or a farmer, or a soldier or a guardian for that matter, could not perform his or her job as well as possible without a certain amount of affection.

In reply it might be said that one will be able to perform one's job better the greater one's degree of psychological contentment, and, other things being equal, the more love one is given the greater one's contentment. Hence, the amount of love one receives will affect one's ability to do one's job.

But there is no evidence that Plato sees the matter in these terms, and if he had, then he would also have had to admit that this provides no justification for a guardian receiving more love than a farmer. Both would benefit equally with regard to their ability to do their work from the affection they receive. Indeed, if 'one's work' is understood to include all of one's social obligations, then it is quite plausible to suggest that the farmer would benefit more than the guardian since the latter's motivation to fulfil his obligations should be much less dependent on such external factors. So, on the basis of FR, there would be no reason to love the city's guardians any more than the city's lowliest farmers, even if the guardian is an exemplar of virtue and wisdom while the farmer is at the bottom of Plato's scale of virtue.

Such a position cannot be seriously attributed to Plato. Rather, the Symposium shows that if distributive justice is meant to apply to the degree of love one accords different objects, it will be determined by the same principle which Vlastos concedes ${ }^{34}$ will govern the distribution of honour ${ }^{35}$ in Plato's ideal city: proportional equality. The enlightened Platonic lover loves good things in proportion to the degree which they deserve or merit, namely in proportion to the degree of beauty and goodness which they exemplify (Symposium 210a-212a; cf. Republic 402d, Laws 757a5-b7). In Plato's city, ties of affection are supposed to unite a citizen to people from different classes as well as to others from his or her own class. If we assume that the Symposium's account holds in the Republic, then we can say that one should love people in proportion to their merit. When $\mathrm{A}$ and $\mathrm{B}$ are equal in merit, $\mathrm{A}$ and B should love one another to the same degree. When A is B's superior, then A deserves more love from $B$ in proportion to the degree in which $A$ is superior to $\mathrm{B}$. So if $\mathrm{A}$ is twice as valuable as $\mathrm{B}$, then $\mathrm{B}$ should love $\mathrm{A}$ twice as much as A loves B. ${ }^{36}$

\footnotetext{
34 'Social Justice', p. 88.

${ }^{35} \mathrm{Cf}$. Aristotle, NE 1159a16-17: 'Being loved appears to be close to being honoured.'

${ }^{36} \mathrm{Cf}$. Aristotle's account of love between unequals in terms of proportionality: $E E$ VII.3; 1241b32-40, 1242b6-15; NE 1158b27-33, 1159a34-b2, 1161a20-22, 1162a15-16, b2-4, 1163a24-b18.
} 
I conclude that Vlastos' objections to the view that proportional equality governs political justice in the Republic are unsuccessful. ${ }^{37}$ The next section will point out some serious difficulties for FR.

\section{II}

Both before and after the Republic, in the Gorgias (508a) ${ }^{38}$ and in the Laws (756e-758a; cf. 744b-d), Plato refers to proportional equality in explaining justice. So if Vlastos were right, Plato would have twice shifted his position on the issue of social justice being considered here. While not impossible, it is more likely that Plato's view remained consistent from the Gorgias to the Laws. More seriously, Vlastos must also claim that Plato's position shifts within the Republic itself, since he concedes that proportional equality determines the Republic's account of political justice on two important points. ${ }^{39}$

(1) As Vlastos concedes, ${ }^{40}$ the distribution of honour in the city is not governed by FR but by proportional equality. Honour may not strike us as a particularly important good for just distribution, but in the Laws (744c) Plato mentions it as one of the goods whose distribution should be governed by

${ }^{37}$ At one point ('Social Justice', p. 88) Vlastos speaks as though he considers another weakness of the proportional equality interpretation to lie in the fact that it only applies to socially distributable compensations, and hence cannot govern the greatest good which the guardians enjoy, the contemplation of Forms. Whether or not there is some way in which this good could be thought to be controlled by social justice in so far as the leisure of the guardians is so controlled, I do not see how the fact that a certain account of social justice only applies to socially distributable goods could be considered an objection against it. Furthermore, if, for the above reason, the distribution of this good is thought to be determined by political justice, proportional equality can handle it for the same reason that FR can. Vlastos would presumably say that, according to FR, the guardians deserve this good because it enables them to perform their work properly. But proportional equality can say exactly the same thing.

${ }^{38}$ Cf. Statesman 257a-b; Epistle 7, 326d. As Morrow says (Plato's Cretan City, p. 524 , n. 10), it is presumably proportional equality that is in question in Diogenes Laertius' report (III, 23) that Plato refused to construct a constitution for the Megalapolitans because they were unwilling to accept equality.

${ }^{39}$ It is also interesting to note that the author of the Magna Moralia (1194a6-25) affirms that proportional equality governs political justice in the Republic.

Some further minor support for the proportional equality interpretation is that Simonides' account of justice - expressed by Socrates at $332 \mathrm{c}$ as giving to each what is

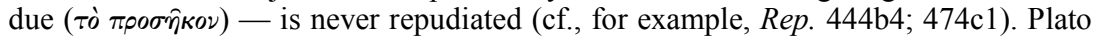
concludes (335e) that 'if ... anyone tells us that it is just to give everyone his due, and he means by this that from the just man harm is due to his enemies and benefit due to his friends - the man which says this is not wise, for it is not true.' Plato 'does not suggest that the rejection of Polemarchus' attempted interpretations of the Simonidean view requires rejection of the view itself.' (T. Irwin, Plato's Ethics (Oxford, 1995),

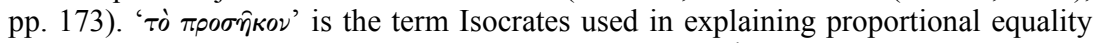

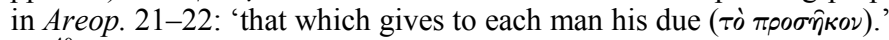

40 'Social Justice', p. 88. See Rep. 414a, 415a. Cf. 425b. 
proportional equality. Likewise, Aristotle considers honour one of the goods of immediate concern for distributive justice. ${ }^{41}$

FR fails to explain the Republic's distribution of this good. What does FR say? 'All members of the polis have equal right to those and only those benefits which are required for the optimal performance of their function in the polis.' So, according to FR, the guardians should be honoured only to the extent required to enable them to perform their job as well as possible. But that would mean that the guardians should not be honoured at all, since they should be able to perform their task of ruling independently of how much honour they receive. However, Plato thinks that they deserve and should receive more honour than anyone else, and after their death they should be honoured as divinities or godlike men. ${ }^{42}$ Receiving honours after death obviously does not contribute anything to anyone's ability to perform a certain task, so it is clear that FR does not explain why Plato thinks this distribution of goods is just. On the other hand, proportional equality explains why the guardians should be honoured so much more than anyone else. One should receive the good of being honoured in proportion to one's merit, and since the guardians deserve this honour so much more than others ${ }^{43}$ they will receive a proportionately greater amount of it.

It is equally obvious that proportional equality, not FR, is needed to explain why neglect of the gods is regarded as unjust (443a): such behaviour fails to accord the gods their due; it does not deprive the gods of what they need to promote the city's wellbeing.

(2) Plato criticizes democracy on the basis of the assumption that proportional equality is the proper account of social justice. In the Laws, when defending proportional equality as the proper account of justice, he says that 'equal treatment of the unequal ends in inequality when not qualified by due proportion. ${ }^{44}$ At Republic 558c Plato objects that democracy distributes 'a kind of equality to equals and unequals alike. ${ }^{45}$ In ancient Greek democracies, political offices were distributed by lot to all the citizens in a city irrespective of their abilities. This is pointed out at Republic 557a where it is said that, in a democracy, the ruling offices are distributed on an equal basis, given, for the most part, by lot. ${ }^{46}$ So when Plato objects that democracy dis-

${ }^{41}$ EN 11130b2, 31.

${ }^{42}$ Rep. 465d-e, 503a, 540b-c. Cf. 468e-469b. 'They will be billionaires of honour in the Platonic state.' Vlastos, 'Social Justice', p. 88.

${ }^{43}$ Why they deserve this honour is not completely clear. Vlastos thinks it will be based on their contribution to the city's wellbeing. $540 \mathrm{~b}-\mathrm{c}$ suggests that it may be based on their outstanding virtue and intelligence.

${ }^{44}$ Laws 757a2-4. A.E. Taylor's translation. Cf. 757d4-5.

${ }^{45}$ Cf. Rep. 453e, 454b, 456b5-6; Gorgias 483c5-6; Aristotle, NE 1131a24.

${ }^{46} \mathrm{Cf}$. $561 \mathrm{a}-\mathrm{c}$ and the contrast drawn in the Laws $(757 \mathrm{~b}-\mathrm{e})$ between proportional equality and choosing by lot. 
tributes a kind of equality to equals and unequals alike, he is saying that equal power (cf. 557a4) in the city is distributed to unequals, i.e. the same power is given to two people despite the fact that the one person may deserve it less than the other in virtue of possessing less ability to rule. He is saying that it is wrong to distribute the same amount of power both to those who deserve it, those who have the ability to rule, and to those who do not deserve it, those who lack any ability to rule. ${ }^{47}$

The implication is that Plato believes that political offices should be distributed on the basis of proportional equality, i.e. the degree of political power one gets should be proportional to one's ability to use it properly. This underlies the question he asks in justification of assigning political power to women as well as men: (456b5-6): 'Must not the same occupations be given to the same natures?' Proportional equality provides the basis for the distribution of political offices in Plato's ideal state. ${ }^{48}$

(3) Plato's second argument for his definition of social justice in Book IV, $433 \mathrm{e}-434 \mathrm{a}$, shows that his conception of justice applies to the right to possession of specific items of private property which one has acquired by legitimate means. Proportional equality explains this while in many cases FR does not.

When the guardians act as judges in lawsuits, Plato says, they will aim at justice, and what they will aim for is 'that no one have what belongs to oth-

Rep. 557-58 shows that F. David Harvey is wrong when he says that Laws 756e758 a is probably the earliest text to make a connection between arithmetical equality and the lot, in 'Two Kinds of Equality', Classica et Mediaevalia 26 (1965), p. 112.

${ }^{47}$ The word Aristotle standardly uses to refer to the quality of a person which determines what good they deserve is ' $a \xi \xi a$ ', 'merit' or 'worth' (see, e.g., $N E$ V.3). In Rep. 434a-b, in his third argument for his definition of political justice, Plato explains that real harm - injustice - occurs to the city when someone with only the ability of a soldier tries to become a guardian, ává $\xi_{10} \dddot{\omega} \nu \nu$. Cf. Laws $744 \mathrm{~b} 6$.

${ }^{48}$ Cf. Derbalov, 'Ursprungsmotive und Prinzipien der Platonischen Staatsdenkens', p. 274, n. 54 and 276. Vlastos ('Social Justice', p. 87) notes that Republic 558c is regularly referred to in support of the idea that proportional equality is upheld in the

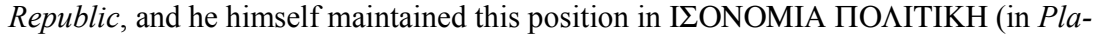
tonic Studies (Princeton, 1973), pp. 193-94). 'Social Justice' still admits that 558c must be understood in terms of proportional equality, but Vlastos now claims (p. 87) that Plato's appeal to the idea is only 'momentary.' Given Vlastos' admission that the Republic also distributes honour according to proportional equality, he is in the position of maintaining that Plato is committed to proportional equality both before and after the Republic, but rejects it in the Republic even though the Republic occasionally appeals to it in deciding questions about justice.

Republic 557-58 shows that Vlastos is wrong to suggest that Plato's avoidance of

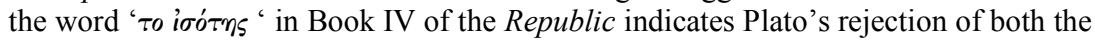
idea of proportional equality and the idea of arithmetical equality ('Rights of Persons', p. 114). 557-58 uses the word while defending proportional equality. 
ers, nor be deprived of what belongs to him. ${ }^{49}$ Suppose that A steals something from B. How can we justify the assertion that it would be just for B to be in possession of this property? FR says B has a right 'to those and only those benefits which are required for the optimal performance of [his] function in the polis.' But it is not going to be true in every case that $\mathrm{B}$ will not be able to do his job as well if his property is not returned to him. So according to FR, when one can do one's job as well without one's stolen property being returned, it will not be just for one to possess that property again. But Plato, who characterizes a just situation as one where people both do and have their own, describes the situation where a person has been robbed (for example) as a case in which someone is deprived of 'his own,' and someone else has what

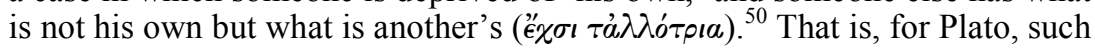
a situation is unjust.

If justice is people having 'their own,' where this is a matter of people having what they merit or deserve, then we can explain how the example fits Plato's definition of justice. For one may deserve and have a right to property one has acquired in a legitimate manner. ${ }^{51}$

${ }^{49}$ Note that 'justice' here characterizes the situation which the judges aim at, not their own action, as in Vlastos' rewriting of the argument ('Social Justice', pp. 7576). Plato argues that (i) the judges will aim at a situation where no one has what belongs to another or is deprived of his own because (ii) such a situation is just. From (i) and (ii) he concludes that the having and doing of one's own is justice. Vlastos claims (p. 76, n. 32) that in the argument as presented the conclusion is 'a wild non sequitur', apparently because he does not see how doing one's own can get into the conclusion from (i) and (ii). The alleged difficulty is removed by noting that the situation described in (i), where 'no one has what belongs to another', can exist only if

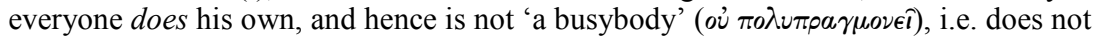
take what belongs to another (as Vlastos himself appears to point out in 'Justice and Happiness in the Republic', Platonic Studies , pp. 121-22).

Vlastos' revision of the argument turns the example into one where the justice at issue is a matter of what Aristotle called rectificatory justice, i.e. a feature of the judge's action which rectifies the (distributively) unjust situation where the robber has what is not his own. But in Plato's example 'justice' rather characterizes the distributively just situation which the judge hopes to bring about.

${ }^{50} 433 \mathrm{e} 7$. At Rep. 344a-b, injustice exists when 'temple robbers, kidnappers, housebreakers, defrauders, and thieves' take 'what belongs to others (

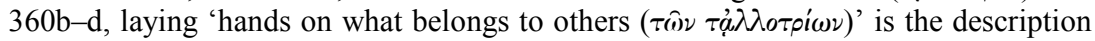
of unjust behaviour.

${ }^{51}$ A similar argument can be given for other examples of unjust behaviour mentioned by Plato at 443a: betrayal, breaking of oaths, adultery, neglect of parents (cf. $463 \mathrm{c}-\mathrm{d}$ ), failure to care for the gods. Even when these actions do not damage the victims' ability to do their work, the situation may be unjust because they have not been given their due. Likewise, Plato clearly does not think that bringing false charges is unjust (565e) solely because it hinders the ability of the accused to do their work; or that the sole reason why it is unjust for a younger man to strike an older man $(465 \mathrm{a}-\mathrm{b})$ is that it would make it more difficult for the older man to carry out his work. 
The connection between the situation Plato envisages and the idea of proportional equality is clear from Aristotle's discussion of distributive justice in Nicomachean Ethics V. The case Plato is talking about is one where, before the situation is rectified, someone has what is not his own and another person has been deprived of what is his own. The person who has grasped what is not his own is guilty of taking more than his due, of $\pi \lambda \epsilon o \nu \epsilon \xi i a$ In Nicomachean Ethics V.1 and 2, it is the contrast with this notion of $\pi \lambda \in \operatorname{cov}_{\epsilon} \xi_{\text {ia }}$ that Aristotle uses to explain the idea of particular justice, i.e. distributive justice, as opposed to generic justice. And he then goes on to explain distributive justice in Nicomachean Ethics V.3 in terms of proportional equality. ${ }^{52}$

(4) In 520a-b, when the question is raised of whether it is just to require the philosophers to participate in the task of ruling the city, Socrates says the following:

Consider that we won't be doing injustice to the philosophers who come to be among us, but rather that we will say just things to them while compelling them besides to care for and guard the others. We'll say that when such men come to be in other cities it is fitting for them not to participate in the labours of those cities. For they grow up spontaneously against the will of the regime in each; and a nature that grows by itself and doesn't owe its rearing to anyone has justice on its side when it is not eager to pay

In the case of justice, someone might reply by saying that if the city is indeed just, everyone will have only what they need to do their work well. So if they are robbed of anything, that will hinder them in performing their work. But while the Republic clearly has egalitarian leanings, there is no reason to believe that Plato thinks the just city can exist only if there is absolute equality of wealth between citizens who perform the same work. The Laws too has egalitarian leanings, but it allows that members of the wealthiest class of citizens may have four times as much wealth as members of the poorest class. So in the just city either the robbed wealthier shoemaker can still perform his work as well as before, or the poor shoemaker who is robbed did not possess everything he needed to do his job as well as possible.

${ }^{52}$ In the Nicomachean Ethics (1132b11-18), Aristotle says:

These names, both loss and gain, have come from voluntary exchange; for

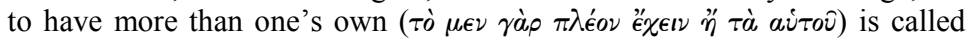
gaining, and to have less than one's original share is called losing; e.g. in buying and selling and in all other matters in which the law has left people free to make their own terms; but when they get neither more nor less but just what belongs to themselves ( $\left.a \dot{i} \tau \dot{a}\langle\tau \dot{a}\rangle \partial^{\prime}{ }^{\prime} a \dot{\nu} \tau \hat{\omega} \nu \gamma^{\prime} \dot{\nu} \eta \tau a l\right)$, they say that

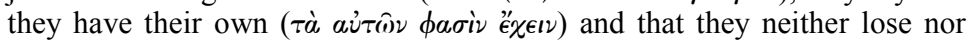
gain.

So it is easy to see how the 'having one's own' formula can apply to the possession of goods acquired in return for services rendered. Here Aristotle applies it to a case in which goods are exchanged, and one 'has one's own' if one receives goods equivalent in value to the goods surrendered to the other person. (Cf. also Laws 918ab). Likewise, there is no problem in seeing how, in the case of involuntary exchange which occurs in the case of theft, the robber can be described as having what is another's and the victim described as not having his own. 
off the price of rearing to anyone. ${ }^{53}$ But you we have begotten for yourselves and for the rest of the city like leaders and kings in hives; you have been better and more perfectly educated and are more able to participate in both lives. So you must go down, each in his turn ...

Note first that, in the just polis, the reason why it is just for the nonphilosophers to receive the benefit of the philosophers' rule is not that they need it to do their jobs but the fact that the philosopher received a benefit from the non-philosophers in the past. This shows that the question of what one needs to perform one's job is not the only consideration that must be taken into account in deciding what is just.

(5) Vlastos can explain why the philosopher who grows up in a non-ideal city has no obligation to benefit others in the city by ruling them: not having 'done their own' they have not fulfilled their obligations to him, and it is only if that condition is satisfied that they have the right to the good of being ruled by the philosopher. However, the fact that other citizens in the unjust polis have not done their own does not mean that they thereby forfeit all their rights. ${ }^{54}$ For example, Plato certainly does not think that philosophers living in non-ideal societies may justly murder or rob whoever fails to do their proper work. The problem for FR is that it cannot explain why. For the rights that it specifies are conditional on the persons in question performing 'their work'.

Recall that doing one's own can refer not merely to the performance of one's specific job but to the entire range of one's public and private obligations to other people. One might try to interpret Vlastos' position as being that one is entitled to certain rights to some degree corresponding to the degree to which one does one's work in the broad sense, where this refers to the entire range of one's obligations. But this is evidently not what Vlastos intended. For he believes that, in Plato's view, the fact that one cannot carry out one's assigned job by itself suffices for the loss of all of one's rights.

53 At 496d Plato describes the philosopher who withdraws from the madness of public life in an unjust city as someone who 'does his own.' So the definition of social justice does not have application solely in the ideal polis: there is a kind of behavior that is doing one's own, is just, even in the non-ideal polis.

${ }^{54}$ Perhaps Vlastos can be understood as arguing against this claim at the end of 'Rights of Persons', pp. 120-23, when he criticizes Plato on the grounds that FR fails to explain why all people 'have equal right to share in those benefits which accrue to individuals from the general observance of moral rules' (p. 121). For example, it fails to explain why all have equal right to the benefits resulting from others' observing moral rules prohibiting murder and robbery. On FR, he says, your rights to such benefits depend on your performing your work role. In response, I am arguing that Vlastos' point rather brings out a problem with his own interpretation of Plato, viz. that Plato does not think all of your rights depend on your work, and this in two ways. (1) It is not the case that you are entitled only to whatever you need to perform a certain job. (2) It is not the case that all or your rights depend on the performance of your job. 
Consider what would happen in this utopia if someone through no fault of his own were to cease being a public asset. One of the philosophers, let us say, becomes permanently disabled and can no longer do his job or any other work that would come anywhere near the expected level of productive excellence ... What may he then claim, now that he may no longer ground his claims on the needs of his job, but only on the value of his individual existence? As I read the Republic, the answer is: Nothing. ${ }^{55}$

Of course, the inability to do a specific job does not mean that one is no longer able to fulfil any of one's moral obligations, and so the disabled philosopher could still continue to do some of the things that constitute 'doing one's own' in the extended sense. But as far as Vlastos is concerned, that would earn him no rights whatever.

(6) Another problem for FR is that it is explicitly restricted to relations between members of the polis, whereas Plato takes it for granted that the notion of justice that he is talking about applies to the relations between one city and another. ${ }^{56}$ Thus, he explains that it is not 'just' for one Greek city to enslave another Greek city, or to allow any other city to do so (469b-c); nor is it just for one Greek city to ravage the countryside or to burn the houses belonging to other Greeks. On the other hand, Plato apparently thinks that there is no injustice in a Greek city so treating a city that belongs to barbarians. Since FR does not apply to inter-city relations, it cannot explain Plato's views about what is just and unjust in such cases. But Proportional Equality can: since Greeks are by nature friends, while Greeks and barbarians are natural enemies $(470 \mathrm{c}-\mathrm{d})$, Greeks do not merit or deserve such treatment from other Greeks; but since Greeks and barbarians are alien in nature, barbarians do merit such treatment from Greeks.

For the same reason, Proportional Equality explains why Plato believes it is unjust for a Greek soldier to enslave another Greek (469c). But it is hard to see how FR could always justify such a rule since a soldier would often be able to do his job better when assisted by a slave.

(7) Vlastos says that the most important issue for the question of political justice is the distribution of political power:

55 'The Individual as Object of Love in Plato', Platonic Studies, p. 15. Note that at $498 \mathrm{~b}-\mathrm{c}$ Plato envisages the guardians retiring from political duties and evidently surviving to study philosophy. And the kind of argument used in 520a-b suggests why Plato would consider it just to allow healthy individuals who are too old to work to continue to live from the goods provided by other citizens. In 520a-b Plato argues that it is just for the rest of the citizens to receive the good of the philosophers' rule in return for the past benefits which the philosophers received from the citizens even though the future philosophers were at that time contributing little to the good of the city as a whole. Likewise, the past benefits which the elderly citizens conferred on the rest of the city can be the basis for the justice of others helping them now even though the elderly citizens are now contributing little to the overall good of the city.

${ }^{56}$ Rep. 332e, 351b, 428d, 469b-471c. 
For Plato's public the question concerning the rights of persons whose urgency remained paramount over that of all other public issues concerned the just allocation of political rights which, for the Greeks, meant the right to direct participation in functions of government and therewith a share in the control of the state. ${ }^{57}$

But a major defect with FR is that it gives us no answer to this question of how political offices should be distributed in the polis.

Vlastos explains FR as follows: Plato's

unstated, but firmly followed, rule is that each has a right to those, and only those, socially distributable benefits which will maximize his contribution, regardless of the ratio which the value of services rendered bears to that of benefits received. . . .

Given this model, and the collateral assumptions which Plato makes about what is best done by whom, the allocation of rights which produces the social structure of the rationally ordered polis of Plato's vision becomes completely lucid. ${ }^{58}$

The italicized phrase refers to

(i) assumptions about what functions are best done by whom,

which are distinguished from

(ii) the model of just distribution.

This indicates Vlastos' tacit recognition of the fact that FR does not itself determine 'what is best done by whom,' i.e. it does not determine what functions are assigned to which people in the city. Hence, it does not determine who is assigned the job of ruling in the city. $\mathrm{FR}^{59}$ presupposes that

57 'Rights of Persons', p. 113; cf. p. 114.

58 'Social Justice' p. 89. My italics.

59 Some other formulations: for people in the polis, 'their function is sole title to the benefits distributed within the polis' ('Social Justice', p. 90, n. 94). 'All members of the polis have equal right to those and only those benefits which are required for the optimal performance of their function in the polis' (p. 110). 'The only benefits one is now allowed of right from the cooperative interchange are those which are required for the optimal performance of one's function' ('Social Justice', p. 112). '[T]he members of the polis are to have only those rights which are required for the optimal performance of their respective function...' ('Social Justice', p. 114). A person 'can claim no benefit for himself except insofar as it would enable him to be a better producer' ('The Individual as an Object of Love in Plato', Platonic Studies, p. 13).

In his paper 'Was Plato a Feminist?' (in Studies in Greek Philosophy, vol. II, p. 141), where his attention is on the justification for allowing women as guardians, Vlastos' formulation is significantly different: 'the rights and duties justly allocated to citizens of the polis would be all and only those which would enable each of them to make the greatest personal contribution to the happiness and excellence of the whole polis' (my italics). If this is accepted, we need to know how we will distribute duties to the citizens in order to ensure that they do the work that makes the city as happy 
functions, including political offices, have already been distributed and so it cannot explain the pattern of distribution advocated by Plato. It says that what you deserve depends on what your function is - ruling, producing, etc. Hence, it answers the question of what goods should be distributed to a person on the basis of the assumption that that person has already been assigned a certain function.

So Vlastos cannot explain why certain people should receive political power on the basis of FR. Before the assignment of a specific function they have no function the performance of which requires certain goods in order to be done as well as possible. We need an account of justice that is independent of FR to determine how political power is to be justly distributed.

Vlastos does say something about the proper grounds for distributing political offices. One qualifies for a certain role in the polis, he says, 'by natural aptitude, by politically provided education, and by excellence of performance. ${ }^{, 60}$ 'The right to participate in the functions of government . .., like every social function, belongs by right to those who can do it best. ${ }^{61}$ But then, of course, it is not one's social function that grounds the assignment of social function.

Rather, the assignment of a certain role in the city will be explained on the basis of proportional equality: one gets the job one merits or deserves - one gets the job one is best able to perform. Thus, Plato believes the guardians alone, because of their preeminent virtue and knowledge, possess the necessary ability to rule the city properly. Since everyone else merits or deserves no political power, everyone else gets no political power. ${ }^{62}$

The assignment of one's job will be covered by the idea of distributive justice, but sometimes it appears that, for Plato, it is not a matter of distributing goods, but rather a matter of distributing the burdens or 'evils' which everyone must endure in a fair manner. This is certainly a matter for which the question of justice or injustice will arise, ${ }^{63}$ but FR only applies to the distribution of benefits. Hence, it does not clearly apply to the distribution of political power, which, as Vlastos points out, the Republic regularly classifies as an example of a good which is intrinsically bad and possess merely instrumental value. ${ }^{64}$

and excellent as possible. I am arguing that the distribution will be in accordance with proportional equality.

60 'Rights of Persons', pp. 110-111.

61 'Social Justice', p. 89.

${ }^{62}$ Note, too, Plato's criticism of the basis of oligarchic rule at 551c: 'would anyone appoint the pilots of a ship this way, by their wealth, and not entrust the ship to a poor man even if he was a better pilot?'

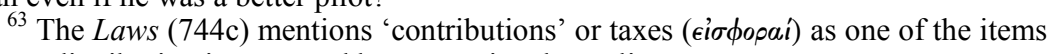
whose distribution is governed by proportional equality.

${ }^{64}$ Rep. 345d-347d, 517c-d, 519c-d, 520c-e, 521b, 540b. Vlastos says that the guardians 'can be expected to make bigger sacrifices in personal happiness for the common good, the biggest of them being the very exercise of the right to govern, 
One final point. There will be no problem about the proportional equality interpretation accommodating Plato's analogy between psychic justice and political justice. In the case of psychic justice, while Plato does speak in terms of distributing goods to parts of the soul by allowing them to experience certain pleasures (586d-587a), the emphasis is on each part of the soul performing its proper task, on each part of the soul doing its own rather than having its own. Injustice exists in the soul when a lower part of the soul at-

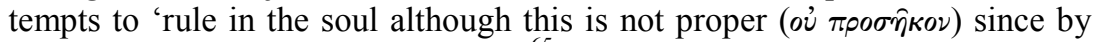

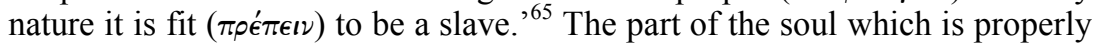
assigned the task of ruling one's life is reason. This deserves to rule ( $\tau \dot{o} \mu \epsilon^{\prime} \nu$

which Plato thinks a painful bore' ('Social Justice', p. 89.). It is hard, then, to see how Vlastos can also say that the performance of one's work in the city 'is for each of these people a privilege, an infinitely precious one, the basis of the worth and meaning of their life, so much so that if ... they were to become unfit to do their work, life would lose its value for them' ('Rights of Persons', p. 112). Likewise, if ruling is a painful bore for the philosopher, how can it be that his vision of the Form of Justice 'fills him with a passionate longing to make it the ordering principle of his own life and of the life of his polis' ('Social Justice', p. 98; my italics)? When Vlastos speaks about justice in the city requiring a sharing of 'burdens' as well as of benefits ('Social Justice', p. 79), the heaviest burden would appear to be the performance of one's job. If the guardians rightly consider ruling of no intrinsic value, it is even clearer that the work of the auxiliaries and producers would have no intrinsic value. How, then, can the performance of this work be 'the basis of the worth and meaning of their life'?

But the conflict in Vlastos' account of the value of one's function does no more than mirror an unresolved conflict in Plato's own position. The Republic is supposed to be demonstrating that doing what is just, including one's work, is an intrinsic good (cf. 497a), and Plato does say that the performance of one's job is necessary if one's life is to be worth living (406d-407a). But Plato often regards the specific actions in which doing what is just is realized as intrinsic evils (as in the passages cited above), or at least as devoid of any intrinsic value $(357 \mathrm{c}-\mathrm{d})$. Plato has no account of the relation between doing what is just and, say, building a house, when one does what is just by building a house.

Irwin tries to help Plato out by saying that all he needs to show is that the guardians value ruling insofar as it is just action, not insofar as it is ruling (Plato's Ethics, pp. 300-301). But this distinction is not found in Plato. And it is an evasion of the problem Plato ought to be facing. The view Plato aims to refute holds that doing injustice is good in itself while doing what is just is evil in itself. The adherents of this view do not think that an unjust action is good qua doing what is unjust and indifferent or worse qua (e.g.) getting possession of gold. It is precisely because an unjust act is a matter of getting possession of another's gold that it appears good. Likewise, doing what is just appears to be an evil because of the specific content of the action in which it is realized - insofar as it is handing over one's money, for example - not insofar as it falls under the description 'doing what is just.' On its own, the demonstration that handing over one's money or ruling is worthwhile only qua doing what is just leaves the position of Plato's opponent untouched. It was not that aspect of the action which anyone found objectionable.

${ }^{65}$ Rep. 444b4. Cf. 442b1-2. 


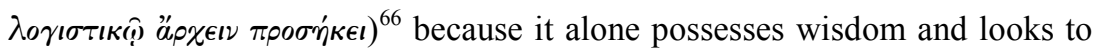
the good of the whole soul (442c). On the other hand, the lowest part of the soul is entirely unfit to rule, and so it is assigned no role in ruling the life of the just person. In the just person, the task of ruling the soul is distributed according to proportional equality - according to merit.

Since, with respect to ruling, reason has all the merit and appetite has none, appetite is the slave of reason in the just soul $(444 \mathrm{~b} 4)$ as the producer is the slave of the guardian in the just state (590c-d; contrast 463b). Psychic justice exists when each part of the soul does its own, and each part of the soul does its own when it does that which is fitting for it to do ( 